\title{
Unresolved issues in pre-meiotic anther development
}

\author{
Timothy Kelliher ${ }^{1}{ }^{*}$, Rachel L. Egger ${ }^{2}$, Han Zhang ${ }^{2}$ and Virginia Walbot ${ }^{2}$ \\ ' Syngenta Biotechnology Inc., Research Triangle Park, NC, USA \\ ${ }^{2}$ Department of Biology, Stanford University, Stanford, CA, USA
}

\section{Edited by:}

Dazhong Dave Zhao, University of

Wisconsin-Milwaukee, USA

Reviewed by:

Scott D. Russell, University of

Oklahoma, USA

Hongchang Cui, Florida State

University, USA

${ }^{*}$ Correspondence:

Timothy Kelliher, Syngenta

Biotechnology Inc., 3054 East

Cornwallis Road, Research Triangle

Park, NC 27709, USA

e-mail: tim.kelliher@syngenta.com
Compared to the diversity of other floral organs, the steps in anther ontogeny, final cell types, and overall organ shape are remarkably conserved among Angiosperms. Defects in pre-meiotic anthers that alter cellular composition or function typically result in male-sterility. Given the ease of identifying male-sterile mutants, dozens of genes with key roles in early anther development have been identified and cloned in model species, ordered by time of action and spatiotemporal expression, and used to propose explanatory models for critical steps in cell fate specification. Despite rapid progress, fundamental issues in anther development remain unresolved, and it is unclear if insights from one species can be applied to others. Here we construct a comparison of Arabidopsis, rice, and maize immature anthers to pinpoint distinctions in developmental pace. We analyze the mechanisms by which archesporial (pre-meiotic) cells are specified distinct from the soma, discuss what constitutes meiotic preparation, and review what is known about the secondary parietal layer and its terminal periclinal division that generates the tapetal and middle layers. Finally, roles for small RNAs are examined, focusing on the grass-specific phasiRNAs.

Keywords: arabidopsis, rice, maize, cell fate specification, tapetum, meiosis, phased small RNA

\section{INTRODUCTION}

Successful anther development results in pollen dispersal. Steps required to achieve this are conveniently divided into three phases: organ patterning and initial cell differentiation, meiosis, and post-meiotic gametophyte development. Historically most studies have focused on meiosis and pollen biogenesis, with the assumption that a simple lineage model explained how the typical four somatic wall layers with central archesporial (AR) cells arose from a stamen primordium (Figure 1A). Starting with recovery and analysis of mutants defective in cell fate specification about 20 years ago (Sheridan et al., 1996; Canales et al., 2002; Zhao et al., 2002; reviewed by Ma, 2005), new theories and molecular insights into the first phase of anther development were proposed, disputed, and continue to be revised and elaborated.

\section{EARLY STEPS IN ANTHER ONTOGENY}

The most detailed description of cellular numbers, shapes, and volumes during fate acquisition is available for maize utilizing 3-D reconstruction from confocal microscopy (Kelliher and Walbot, 2011) rather than transverse sectioning. Patterning to achieve the four somatic wall layers and central pre-meiotic cells typical of anther lobes is summarized in Figure 1B, employing pale coloration to indicate initial specification, with cell types darkening as differentiated features emerge. First, note that these stages, numbered one through eight, are processes, not discrete events. For example, starting from a primordium full of pluripotent cells, AR cells are the first to differentiate in anther lobes. In maize, discrete differentiation events from different precursors generate a column of $\sim 10$ AR cells over the course of 1 day. The first molecular marker of differentiating AR cells is MAC1 secretion; this ligand triggers pluripotent subepidermal cells to become bipotent Primary Parietal Cells (PPC) (Figure 1B, stage 2). The PPC then divide once periclinally to generate Endothecium (EN) and Secondary Parietal Layer (SPL) cells (Figure 1B, stage 3). In a given transverse section these steps occur successively, but viewing the anther longitudinally it is clear that AR differentiation in the anther base and tip occurs simultaneously with PPC periclinal divisions in the middle of the lobe (Figure 1C). Although it was long assumed that L1 presumptive epidermal cells and L2 internal cells have distinct fates locked in by their positions within an apical meristem, maize AR cells can differentiate from L1 cells during stage 2 low oxygen treatments: thus it appears that every maize anther primordium cell is pluripotent (Kelliher and Walbot, 2012). These observations lay to rest the lineage model where germinal and somatic cell fates diverge from a single "hypodermal cell" division event within each lobe.

Periclinal divisions generate new anther cell types and add cell layers to the anther wall, but most anther cell division is anticlinal (within layers). In maize a rapid elongation phase featuring exclusively anticlinal divisions prolongs stage 4 (Figure 1B), prior to SPL periclinal division into the Middle Layer (ML) and Tapetum (TAP) (Figure 1B, stages 5-7). This is followed by a second phase of rapid anther growth, prior to differentiation of post-mitotic AR cells into meiotically competent Pollen Mother Cells (PMC) (Figure 1B, stage 8). Although rice anthers are similar in size to maize during AR specification, both periods of rapid anticlinal cell division and expansion are absent (Figure 1B). As a result rice anthers starting meiosis are about one-third the length of maize; in rice, there is substantial anticlinal division during and just after 


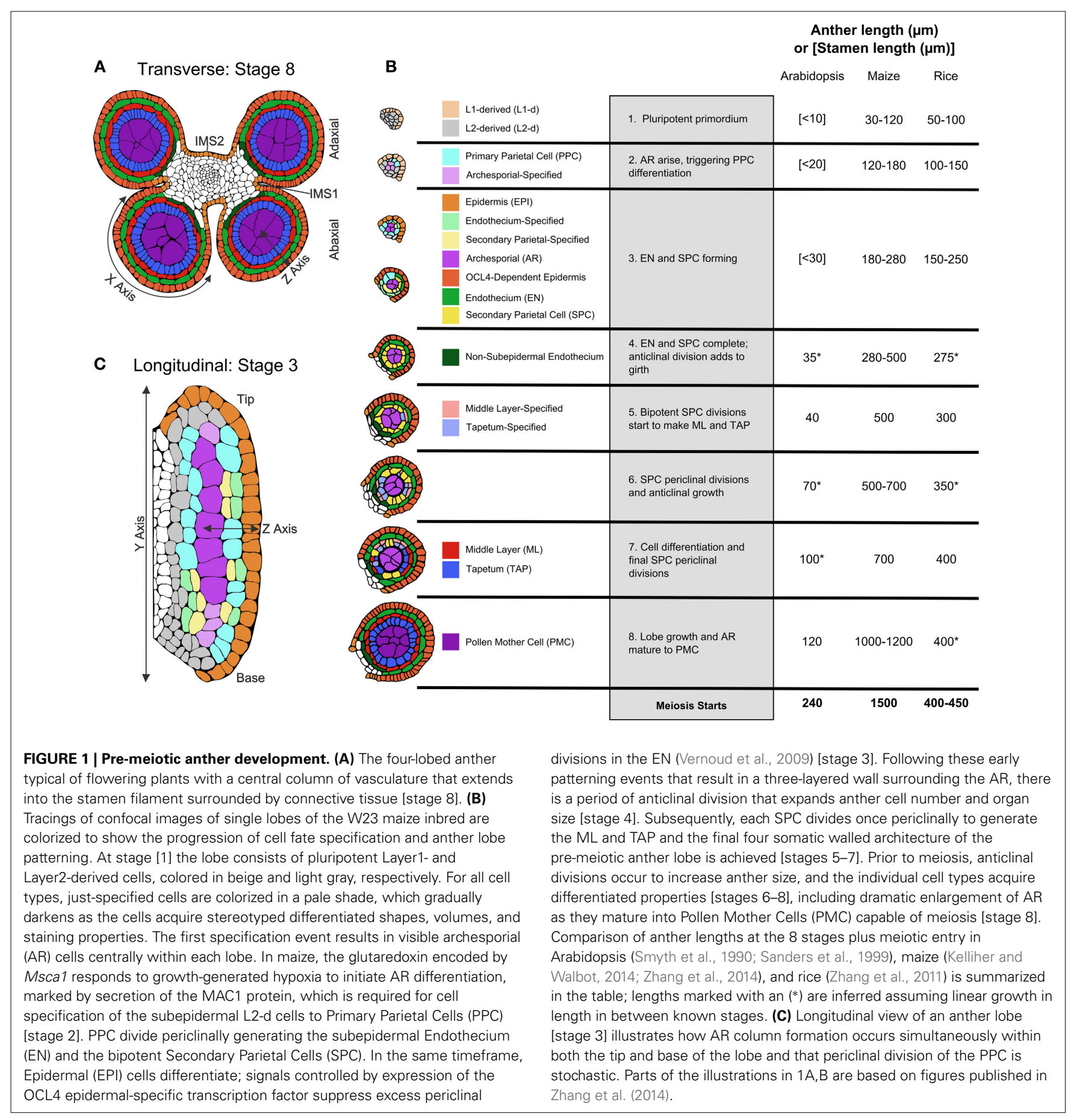

meiosis. Arabidopsis anther primordia are considerably smaller than either grass-a combination of fewer, smaller cells-and like rice there is only modest pre-meiotic growth.

Given conserved internal anther anatomy, we expect similar regulatory processes among different flowering plants. Highlights of these common themes include: (1) many anther-specific mutants (Ma, 2005; Timofejeva et al., 2013); (2) a complex and dynamic transcriptome (Zhang et al., 2014); (3) communication between cell layers using secreted proteins (Wang et al., 2012); (4) presumptively locally produced hormones (Zhang et al., 2014), and (5) developmentally regulated small RNAs (Johnson et al., 2009). It is difficult to propose imposition of hormone or other gradients from materials delivered through the central vasculature (Figure 1A). Thus, unanswered questions include how the pace of anticlinal cell division is regulated autonomously within an anther lobe and what specific cues (activators and repressors) regulate periclinal divisions. It is striking that $\mathrm{AR}$ and later PMC development does not require normal somatic layers, as documented for the maize macl mutant (Wang et al., 2012). Indeed, once specified, AR cells express a unique transcriptome, 
including precocious synthesis of transcripts for meiotic proteins, and robust production of transcripts for ribosomes and RNA binding proteins (Kelliher and Walbot, 2014). A major unanswered question is whether anther cell types express but then sequester mRNAs for use at later stages, a developmental mechanism widely employed in animal germlines (Zhang et al., 2014).

\section{INITIAL EVENTS RESULTING IN AR COLUMN FORMATION}

A major breakthrough in plant reproductive genetics was identification of the Arabidopsis transcription factor SPOROCYTELESS (SPL) which was shown to be essential to AR cell differentiation and meiotic entry in both anthers and ovules (Yang et al., 1999). The late onset of AR-specific expression ( stage 4 ), however, suggested that SPL is only involved after initial fate acquisition, which at the time was thought to depend upon the inheritance of reproductive determinants via asymmetric periclinal division of a single founding hypodermal cell in each lobe. This lineage model ruled the field for decades, largely because early-acting mutants were challenging to identify and characterize, especially in Arabidopsis and rice. Then, in 2003 Chaubal et al. reported on a maize mutant, male sterile converted anther1 (msca1), in which AR cells failed to form and were replaced by vascular bundles. When MSCA1 was identified as a glutaredoxin (Albertson et al., 2009), and homologs were shown to affect AR fate acquisition in rice (Hong et al., 2012) and Arabidopsis (Xing and Zachgo, 2008), the first connection between protein redox status and plant reproductive cell fate was made.

The application of confocal microscopy enabled a detailed morphometric analysis of AR column formation, which established that instead of just one founding germinal cell per lobe determined by inheritance, there were many initial AR cells specified from multiple progenitors. The lineage model was incorrect, and it was proposed that the internal position of AR cells within lobes determined their ultimate fate (Kelliher and Walbot, 2012). It was reasoned that such internal cells should be more hypoxic than their neighbors because of the high metabolic demand of rapid proliferation and the lack of air space in the tightly packed tissue (Figure 2A). To test the idea, hypoxia treatments were applied and rescued AR fate acquisition in mscal, dramatically increased AR cell counts in fertile anthers, and stimulated ectopic AR formation in both fertile and mutant anthers (Kelliher and Walbot, 2012). While redox manipulations were not attempted in other species, the mutant phenotypes of Mscal homologs in rice (MIL1) (Hong et al., 2012) and Arabidopsis (ROXY1/ROXY2) (Xing and Zachgo, 2008) indicate that glutaredoxin-based control of AR fate might be a conserved feature across flowering plants.

A major unanswered question is whether MSCA1 is expressed and active in the pluripotent L2-d cells surrounding the AR column, which experience mild hypoxia but will acquire a somatic fate. Glutaredoxins such as MSCA1 are known to bind and activate bZIP-type TGA transcription factors (Murmu et al., 2010); we hypothesize that among the MSCA1 targets are transcription factors that promote Macl expression, the first molecular marker of AR fate acquisition. A secreted peptide, MAC1 signals pluripotent cells to differentiate as PPC (somatic) and divide periclinally forming the EN and SPL (Figure 2B). If MSCA1 is active

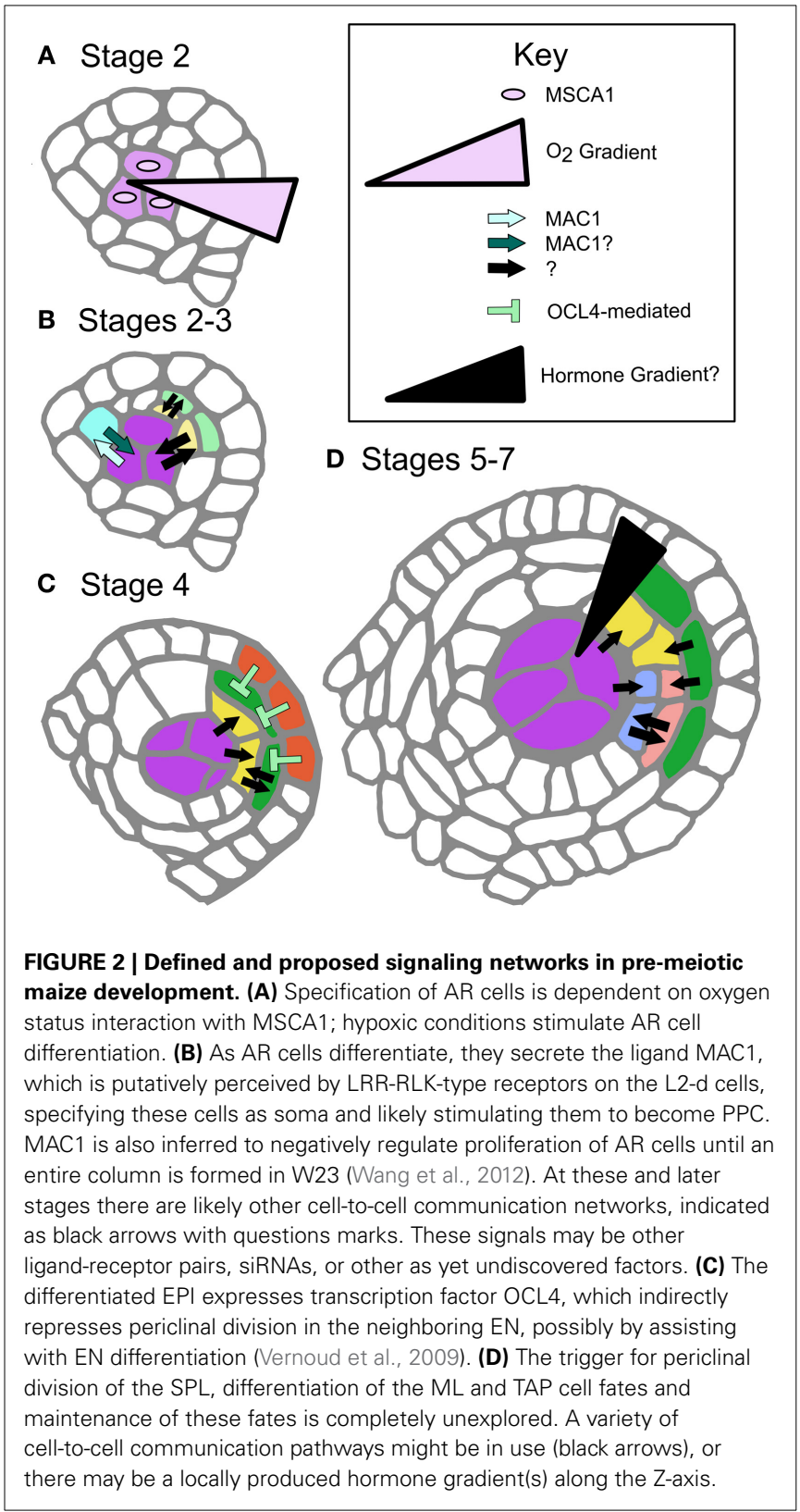

in these presumptive PPCs, how does MAC1 signaling counteract or attenuate MSCA1 activity, overcoming mild hypoxia to enforce a somatic destiny? Likewise, does low oxygen tip the balance toward MSCA1 in the growing AR column, where newborn AR cells differentiate despite MAC1 secretion from existing AR cells (Figure 1C)? Ectopic AR cells arising from redox manipulation have column-forming abilities, even in macl; therefore, column formation may be an emergent property of AR cells that is neither inhibited nor promoted by MAC1. Future work will continue to examine potential interactions between MSCA1 and MAC1 with respect to column formation.

Reproductive cell fate acquisition has put glutaredoxins at the forefront of the study of the genetic-environmental interface. These proteins appear to provide flexibility and responsiveness to hard-wired developmental programs and continue to be 
implicated in diverse plant developmental processes. In rice, the mill glutaredoxin affects AR and SPL cell fate following AR differentiation (Hong et al., 2012) (stages 3-4), while the Arabidopsis glutaredoxin double mutant roxy1/2 differentially affects ab- and ad-axial AR development (Xing and Zachgo, 2008), causing defects in stage 2 adaxial lobes and stage 7 abaxial lobes, implying a continued requirement for redox management during anther development and the involvement of multiple glutaredoxins in the differentiation of both germinal and somatic anther tissues. Mis-expression of MSCA1 in the shoot apical meristem gives opposite phyllotaxy in Abph2 (Jackson et al., 2013), demonstrating the power of this protein to influence body plan elaboration. While genetic programming has a major role in early anther development-initial AR cell counts vary among inbred lines from $\sim 10$ in W23 to $\sim 25$ in A619hypoxic treatments can double or triple initial AR counts without forcing a trade off in somatic cell populations. Therefore, the initial size of the AR population is controlled by both genetic factors and environmental conditions, and pollen production can be manipulated via genetic or extrinsic, redox-based treatments.

\section{PATTERNING THE ANTHER SOMATIC NICHE}

The somatic niche surrounding the developing AR cells is equally important for anther fertility. Contingent on MAC1-mediated signaling, L2-d cells are specified as somatic niche cells. The first morphological marker of somatic fate is PPC periclinal division that results in two somatic daughter cells (stage 3), that through subsequent periclinal divisions will differentiate as EN, ML, and TAP (Kelliher and Walbot, 2011; Timofejeva et al., 2013). Although EN, SPL, ML, and TAP cells are typically represented as differentiating immediately after a periclinal division, this is an over-simplification. Indeed, careful analysis of cell shape in maize indicates that these cells must expand in preferential dimensions before gradually achieving mature cell morphology (Kelliher and Walbot, 2011). Borrowing terminology from animal development, we consider somatic cells as passing through multiple steps, starting with cell fate specification, commitment, and finally differentiation. Periclinal division is the first marker of specification, and differentiation has occurred by the morphological end-point, but without deeper knowledge of cellular and molecular details, determining commitment timing is impossible. Does specification occur before a periclinal division, or after? When is commitment reached, and how are we to interpret the numerous mutants that persist in making periclinal divisions, i.e., ocl4, $m s 23$, and $m s 32$ in maize (Chaubal et al., 2000; Vernoud et al., 2009; Moon et al., 2013, Figure 2C), and tdf1 in Arabidopsis (Zhu et al., 2008)?

A second issue is within-layer stochasticity in periclinal division initiation. AR cells initiate meiosis synchronously, yet the periclinal divisions resulting in the EN/SPL and later the ML/TAP are both asynchronous and exhibit no discernible spatial pattern (Kelliher and Walbot, 2011; Zhang and Li, 2014). Each cell appears to divide periclinally after a variable number of anticlinal divisions. Could signals directing periclinal divisions be perceived during a restricted portion of the cell cycle, resulting in a large population of cells deaf to the signal when first available?
Asynchrony of anticlinal somatic division would then result in asynchrony of periclinal divisions.

The complexity and lack of information on signaling within the soma makes investigations into the regulation of somatic cell patterning and specification in the anther ripe for pursuit. Despite the relative dearth of information, there are some hints that allow predictions (Figure 2). First, the secreted peptide and receptor model may be a common theme. Mutants in Arabidopsis and rice homologs AtTPD1 and OsTDL1A have excess AR cells but develop a normal EN and SPL (stage 5, Figure 1B) (Feng and Dickinson, 2010). Clues from these mutants suggest the MAC1 peptide family binds LRR-RLK receptors (AtEXS/EMS1 and OsMSP1, respectively). As LRR-RLKs are known to dimerize, hetero-dimerization utilizing different isoforms or family members may contribute to differential signal interpretation in peripheral L2-d and presumptive AR cells during column formation, or between other cell types at later stages (Wang et al., 2012). Elucidating the suite of LRR-RLKs could uncover a distinct "combinatorial code" of dimeric receptors on different cell types. This idea is consistent with the presence of many putatively secreted peptides (Wang et al., 2012) and the expression of numerous LRRRLKs in anthers (Kelliher and Walbot, 2014; Zhang et al., 2014). The anther is one of many organs where peptide signaling has emerged as a major developmental paradigm. In particular, tissues that lack direct access to vasculature, such as stem cells in the shoot apical meristem and meristemoid cells of the stomatal lineage (Li and Torii, 2012), often employ this mode of cell-cell communication.

The role of hormones or other chemical gradients within anther lobes is another area yet to be explored on a cell typespecific level. In a commonly cited example, periclinal division in Arabidopsis roots involves an auxin gradient delivered by polarized auxin flow (Cruz-Ramirez et al., 2012). Given the anatomy of the anther, it is unlikely that a similar flow exists because cell types are not a uniform distance from the vasculature. Local hormone production and perception would more likely be a feature of anther development (Figure 2D). Transcriptome analysis indicates that both gibberellin and brassinolide associated genes are differentially regulated in stage 7 pre-meiotic anther development; these would make strong initial candidates for further exploration as regulators of anther cell fates (Zhang et al., 2014).

Despite identification of many maize male-sterile mutants disrupting pre-meiotic somatic patterning (Table 1), this phase of early anther development is underrepresented in the rice and Arabidopsis literature. The small size of rice and Arabidopsis anthers at these stages $(20-70$ and $100-350 \mu \mathrm{m}$, respectively, compared to $120-700 \mu \mathrm{m}$ for maize) along with the rapidity of development (in maize, events span nearly 3 days, roughly twice as long as Arabidopsis) makes isolation and precise analysis of discrete stages difficult (Figure 1B). Many mutants that fail to complete meiosis have been categorized as meiotic mutants, even when the defect is earlier and the primary defect is in the soma. There is no consensus concerning the specific roles of each somatic cell type. The tapetum has been characterized as a highly transcriptionally active, secretory cell type required for exine formation. But the ML can be present as either a 
Table 1 | A comprehensive list of anther mutants sequentially organized from organ specification through meiosis.

\begin{tabular}{|c|c|c|c|c|c|c|}
\hline $\begin{array}{l}\text { Stage } \\
\text { affected }\end{array}$ & A. thaliana & Rice & Maize & Annotation & Phenotype & doi \\
\hline 1 & agamous & mads3, mads58 & Zmm2, Mads2 & $\begin{array}{l}\text { MADS-box } \\
\text { transcription } \\
\text { factor }\end{array}$ & $\begin{array}{l}\text { stamens converted to petals } \\
\text { (Arabidopsis) or lodicules } \\
\text { (grasses) }\end{array}$ & 10.1105/tpc.3.8.749 \\
\hline 1 & & & $\begin{array}{l}\text { ems71924, } \\
\text { ems72032 }\end{array}$ & not cloned & stamen adaxialization & $10.1534 / g 3.112 .004465$ \\
\hline 1 & & & $\begin{array}{l}\text { ems71990, } \\
m s-s i^{*} 355\end{array}$ & not cloned & $\begin{array}{l}\text { absence of anthers in some } \\
\text { florets }\end{array}$ & $10.1534 / g 3.112 .004465$ \\
\hline 1 & rdr6 & $\begin{array}{l}\text { rol } \\
\text { (SHOOTLESS2) }\end{array}$ & rdr6 & $\begin{array}{l}\text { RNA-directed } \\
\text { RNA polymerase }\end{array}$ & $\begin{array}{l}\text { stamen abaxialization (defect } \\
\text { in tasi-ARF biosynthesis) }\end{array}$ & 10.1105/tpc. 110.075291 \\
\hline 2 & $\begin{array}{l}\text { bam1 bam2 } \\
\text { double mutant }\end{array}$ & & & $\begin{array}{l}\text { LRR receptor-like } \\
\text { kinases }\end{array}$ & $\begin{array}{l}\text { all internal lobe cells become } \\
\text { AR; no somatic cells }\end{array}$ & 10.1105/tpc. 105.036871 \\
\hline 2 & & mil1 & msca1 & glutaredoxin & $\begin{array}{l}\text { AR fail to differentiate }(O s) \text { or } \\
\text { differentiate as vasculature } \\
(Z m)\end{array}$ & $\begin{array}{l}10.1007 / \mathrm{s} 00425-002- \\
0929-8\end{array}$ \\
\hline $\begin{array}{l}2(\mathrm{ad}), 8 \\
(\mathrm{ab})\end{array}$ & $\begin{array}{l}\text { roxy1 roxy2 } \\
\text { double mutant }\end{array}$ & & & $\begin{array}{l}\text { glutaredoxin } \\
\text { (thioreductase) }\end{array}$ & $\begin{array}{l}\text { adaxial lobes: AR } \\
\text { specification failure; abaxial: } \\
\text { PMC degrade }\end{array}$ & $\begin{array}{l}\text { 10.1111/j.1365- } \\
313 \times .2007 .03375 . x\end{array}$ \\
\hline 3 & $n z z=s p l$ & no homolo & in grasses & $\begin{array}{l}\text { MADS-box } \\
\text { transcription } \\
\text { factor }\end{array}$ & $\begin{array}{l}\text { AR differentiation failure; } \\
\text { somatic cell layer defects }\end{array}$ & 10.1104/pp. 109.145896 \\
\hline $\begin{array}{l}3 \\
(\mathrm{Zm} / \mathrm{Os}) \\
5(A t)\end{array}$ & tpd1 & $t d l 1 a=$ mil2 & $\operatorname{mac1}$ & $\begin{array}{l}\text { small secreted } \\
\text { protein ligand }\end{array}$ & $\begin{array}{l}\text { somatic cell specification } \\
\text { failure; overproliferation of AR }\end{array}$ & 10.1105/tpc.016618 \\
\hline 3 & $e x s=e m s 1$ & msp1 & & $\begin{array}{l}\text { LRR receptor-like } \\
\text { kinase }\end{array}$ & $\begin{array}{l}\text { somatic cell specification } \\
\text { failure; overproliferation of AR }\end{array}$ & $\begin{array}{l}\text { 10.1016/S0960- } \\
9822(02) 01151-x\end{array}$ \\
\hline 4 & & & oc/4 & $\begin{array}{l}\text { HD-ZIP IV } \\
\text { transcription } \\
\text { factor }\end{array}$ & $\begin{array}{l}\text { additional periclinal divisions } \\
\text { in subepidermal cell layer }\end{array}$ & $\begin{array}{l}\text { 10.1111/j.1365- } \\
313 \times .2009 .03916 . x\end{array}$ \\
\hline 4 & & & $\begin{array}{l}\text { ems63089, tc/1, } \\
\text { mtm00-06 }\end{array}$ & not cloned & $\begin{array}{l}\text { undifferentiated somatic cell } \\
\text { layers }\end{array}$ & $10.1534 / g 3.112 .004465$ \\
\hline 5 & & tip2 & & $\begin{array}{l}\text { bHLH } \\
\text { transcription } \\
\text { factor }\end{array}$ & $\begin{array}{l}\text { all three anther wall layers fail } \\
\text { to differentiate properly }\end{array}$ & 10.1105/tpc. 114.123745 \\
\hline 5 & $\begin{array}{l}\text { er erl1 erl2 triple } \\
\text { mutant }\end{array}$ & & & $\begin{array}{l}\text { LRR receptor-like } \\
\text { kinases }\end{array}$ & $\begin{array}{l}\text { missing anthers and somatic } \\
\text { cell differentiation defects }\end{array}$ & 10.1093/mp/ssn029 \\
\hline 6 & $t d f 1$ & & & $\begin{array}{l}\text { R2R3 Myb } \\
\text { transcription } \\
\text { factor }\end{array}$ & $\begin{array}{l}\text { early vacuolization in } \\
\text { epidermis and endothecium, } \\
\text { tapetal failure }\end{array}$ & $\begin{array}{l}\text { 10.1111/j.1365- } \\
313 \times .2008 .03500 . x\end{array}$ \\
\hline 6 & $\begin{array}{l}\text { serk1 serk2 } \\
\text { double mutant }\end{array}$ & & & $\begin{array}{l}\text { LRR receptor-like } \\
\text { kinases }\end{array}$ & SPL periclinal division failure & 10.1105/tpc. 105.036731 \\
\hline 7 & & & $m s 23, m s * 6015$ & not cloned & $\begin{array}{l}\text { additional periclinal divisions } \\
\text { in the tapetal layer }\end{array}$ & $10.1534 / g 3.112 .004465$ \\
\hline
\end{tabular}




\section{Table 1 | Continued}

\begin{tabular}{|c|c|c|c|c|c|c|}
\hline $\begin{array}{l}\text { Stage } \\
\text { affected }\end{array}$ & A. thaliana & Rice & Maize & Annotation & Phenotype & doi \\
\hline 7 & & & ems72063 & not cloned & $\begin{array}{l}\text { undifferentiated soma; } \\
\text { excess periclinal divisions in } \\
\text { tapetum }\end{array}$ & $10.1534 / g 3.112 .004465$ \\
\hline 7 & & & ems72091 & not cloned & $\begin{array}{l}\text { additional periclinal divisions } \\
\text { in the middle layer }\end{array}$ & $10.1534 / g 3.112 .004465$ \\
\hline 7 & mpk3 and mpk6 & & & MAP kinases & $\begin{array}{l}\text { somatic cell specification } \\
\text { failure; overproliferation of AR }\end{array}$ & $10.1093 / \mathrm{mp} / \mathrm{ssn} 029$ \\
\hline 8 & & $d t m 1$ & & $\begin{array}{l}\text { ER membrane } \\
\text { protein }\end{array}$ & tapetal differentiation failure & $\begin{array}{l}\text { 10.1111/j.1365- } \\
313 \times .2011 .04864 . x\end{array}$ \\
\hline 8 & $\begin{array}{l}\text { myb33 myb65 } \\
\text { double mutant }\end{array}$ & & & $\begin{array}{l}\text { GAMYB-like } \\
\text { transcription } \\
\text { factor }\end{array}$ & tapetal differentiation failure & 10.1105/tpc. 104.027920 \\
\hline 8 & & & $\begin{array}{l}\text { ms9, ms11, } \\
m s 13, m s 14\end{array}$ & not cloned & tapetal differentiation failure & $10.1534 / \mathrm{g} 3.112 .004465$ \\
\hline 8 & & & ms32 & $\begin{array}{l}\text { bHLH } \\
\text { transcription } \\
\text { factor }\end{array}$ & $\begin{array}{l}\text { excess periclinal divisions in } \\
\text { tapetum after normal wall is } \\
\text { built }\end{array}$ & 10.1111/tpj.12318 \\
\hline 8 & & & csmd1 & not cloned & $\begin{array}{l}\text { excess pre-meiotic callose } \\
\text { and slow dissolution of the } \\
\text { tetrad }\end{array}$ & $\begin{array}{l}\text { 10.1007/s00497-011- } \\
0167-y\end{array}$ \\
\hline meiosis & & $u d t 1$ & & $\begin{array}{l}\text { bHLH } \\
\text { transcription } \\
\text { factor }\end{array}$ & $\begin{array}{l}\text { tapetal differentiation failure; } \\
\text { meiotic arrest }\end{array}$ & 10.1105/tpc. 105.034090 \\
\hline meiosis & & mel1 & & Argonaute & $\begin{array}{l}\text { tapetal differentiation failure; } \\
\text { meiotic arrest }\end{array}$ & 10.1105/tpc. 107.053199 \\
\hline
\end{tabular}

The left hand column indicates the first developmental stage at which a mutant phenotype is observed, using the staging rubric outlined in Figure 1. In cases where the onset of the phenotype differs among species or tissues, abbreviations are used ("Zm" = maize, "Os" = rice, "At" = Arabidopsis, "ab" = abaxial anther lobes, and "ad" = adaxial anther lobes). If a given mutant is phenocopied by homologs from the other two species, the gene names are given in the corresponding species' column. An exception to this rule was made for the first maize entry, "Zmm2, Mads2," because while mutants in these genes have not been found, the genes are clearly agamous orthologs by sequence comparison and expression pattern in the third floral whorl, which is characteristic of $C$ class genes. The next two columns contain the phenotypic description of the mutant and protein annotation if a causative gene has been cloned. Uncloned mutants are indicated as "not cloned," and these are clustered in a single row in cases where they roughly phenocopy each other (for example, maize ems71924 and ems 72032 have nearly identical anther polarity phenotypes, and may be allelic). In the final column, a doi is provided for the founding mutant of each class. The high number of blank spaces in the species' columns reflects the challenge of comparisons between model species. The bHLH, MYB, and LRR-RLK genes are all found in large families making identification of orthologs between species problematic. Furthermore, mutations in a single gene that cause a clear phenotype in one plant species may not be available in others because of functional gene redundancy from lineage specific gene duplication. And there is already evidence that orthologs can regulate different steps reflecting evolutionary diversification of developmental pathways. For these reasons we do not anticipate a high degree of correspondence between Arabidopsis, rice, and maize. 
single layer (as in rice, maize, and Arabidopsis), or several layers, but is always consistent within a species (Esau, 1965; D'Arcy and Keating, 1996). Middle-layer like tissue and dartboard lobe architecture are relatively ancient, dating to the gymnosperm microsporangia (Esau, 1965; D'Arcy and Keating, 1996), but as of yet no specific function has been proposed for the ML. Secondary wall thickening of the EN is involved in anthesis at the end of anther development, but no attention has been given to earlier roles. Germ cell establishment and the subset of tapetal mutants that result in meiotic arrest have received the vast majority of attention.

\section{ROLE OF SMALL RNAs IN ANTHER PATTERNING}

Developing anthers depend on small RNAs for gene regulation, cell-to-cell communication, and epigenetic reprogramming. For example, in rice, anther adaxial-abaxial polarity is regulated by trans-acting siRNAs (tasiRNAs), which are secondary siRNAs derived from TAS transcripts (Toriba et al., 2010). These transcripts are first processed by miRNA-guided cleavage and then converted to double-stranded RNAs by RNA-dependent RNA polymerase6 (RDR6), followed by Dicer4 (DCL4) cleavage yielding 21-nt tasiRNAs (Allen et al., 2005). Mutants that disable components of the tasiRNA biogenesis pathway display severe defects in floral morphology and fertility. Rice $d c l 4$ exhibits a disruption in lemma abaxial-adaxial polarity and abnormal anther development (Liu et al., 2007). In the rod-like lemma (rol/rdr6) mutants, stamen, and lemma development are severely compromised (Toriba et al., 2010). A single nucleotide polymorphism in the same gene results in reduced fertility at high temperature (Song et al., 2012a). The phenotypes of these mutants are largely caused by loss of tasiRNAs, resulting in upregulation of target Auxin Response Factor genes required for abaxial identity (Pekker et al., 2005).

Recently two size classes of phased siRNAs (phasiRNAs) were found to be preferentially expressed in grass inflorescences, particularly in anthers (Johnson et al., 2009; Song et al., 2012b). Both phasiRNA types are derived from low copy intergenic regions, and each requires a specific miRNA trigger (miR2118 for the 21-nt class and miR2275 for 24-nt class) to initiate cleavage and RDR6-dependent second-strand synthesis. The resulting double-stranded RNAs are then cleaved by DCL4 to produce 21-nt phasiRNAs and by DCL5 for 24-nt phasiRNAs (Arikit et al., 2013). Despite similarities to tasiRNA biogenesis, the functions of these 21- and 24-nt phasiRNAs and their targets are largely unknown. The phasiRNAs lack complementarity to genes or transposons, suggesting novel roles rather than post-transcriptional gene silencing or RNA-directed DNA methylation.

Post-meiotically, small RNAs do provide germinal cell genome surveillance in microspores. Triggered by miRNAs and dependent on RDR6 and DCL4 (Creasey et al., 2014), the 21-nt epigenetically-activated siRNAs (easiRNAs) are derived from transposon transcripts exclusively expressed in the vegetative nucleus of Arabidopsis pollen grains; easiRNAs then move to sperm cells to direct transcriptional gene silencing (Slotkin et al., 2009). As a result, sperm cell chromatin is highly condensed and enriched in the repressive epigenetic modifications while chromatin in the vegetative cell nucleus is largely decondensed (Slotkin et al., 2009).

Despite sharing biogenesis factors including DCL4 and RDR6, 21-nt phasiRNAs are different from 21-nt easiRNAs in three ways. First, although 21-nt phasiRNAs have been found in dicots, they are mostly derived from a single $N B-L R R$ defense gene family (Zhai et al., 2011); in contrast hundreds of grass loci encode phasiRNAs. Second, phasiRNAs are produced prior to meiosis or gametogenesis (Komiya et al., 2014) while easiRNAs are found specifically in gametophytes. Third, easiRNAs are derived from repetitive regions, while phasiRNAs are produced from unique or low copy sequences. These distinctions between phasiRNAs and easiRNAs suggest their functional divergence and imply a sporophytic role for phasiRNAs in anther development.

ARGONAUTE proteins have diverged rapidly in plants, with 10 members in Arabidopsis (Chen, 2009), 19 in rice (Kapoor et al., 2008), and 17 in maize (Zhai et al., 2014); many are preferentially expressed in germinal cells (Zhai et al., 2014). The continued diversification of ARGONAUTEs suggests that many new functions for small RNAs during plant reproduction await discovery. MEL1, a rice homolog of Arabidopsis AGO5, mainly localizes to the cytoplasm of pre-meiotic sporocytes. mell loss-of-function mutants exhibit abnormal tapetal formation and contain aberrant PMC that arrest in early meiosis (Nonomura et al., 2007). Recently MEL1 was demonstrated to bind 21-nt phasiRNAs preferentially (Komiya et al., 2014). Histone methylation patterns are altered in mel1 mutant meiocytes (Nonomura et al., 2007), hinting at a role for MEL1 and its associated 21-nt phasiRNAs in chromatin modification. Because the tapetal somatic defect precedes the documented meiocyte phenotypes in mell anthers, it is not yet clear if MEL1/21-nt phasiRNAs act directly or indirectly to disrupt meiosis.

Maize AGO104 is a homolog of Arabidopsis AGO9 and its transcripts accumulate specifically during pre-meiosis just following germinal differentiation in anthers (Kelliher and Walbot, 2014) and during meiosis (Singh et al., 2011). Maize ago104 mutants show defects in meiotic chromatin condensation and subsequent failure to properly segregate chromosomes (Singh et al., 2011). Small RNAs interacting with AGO104 are yet to be profiled, but the heterochromatic decondensation in maize ago104 mutants suggests a role in germinal cell epigenetic reprogramming. With rapid progress in deep sequencing of small RNAs and RNA-IPseq, we are likely to acquire a better understanding of the diverse ways small RNAs contribute to anther development and plant reproduction.

\section{AUTHOR CONTRIBUTIONS}

Each author wrote one section of the manuscript, edited all sections, and approved final submission.

\section{ACKNOWLEDGMENTS}

Support for our research on pre-meiotic maize anthers was from NSF 07-01880. As a graduate student at Stanford, Timothy Kelliher was supported by an NIH Biotechnology Training Grant (5-T32-GM008412-17). Rachel L. Egger was supported in part by an NIH Cell and Molecular Biology Training Grant (5T32GM007276-36), by the 2013 American Society of Plant 
Biologists-Pioneer Hi-Bred Graduate Student Fellowship, and by an Agriculture and Food Research Initiative Competitive Grant from the USDA National Institute of Food and Agriculture (201367011-21096).

\section{REFERENCES}

Albertson, M. C., Fox, T., Trimnell, M., Wu, Y., Lowe, K., Li, B., et al. (2009). Msca1 Nucleotide Sequences Impacting Plant Male Fertility and Method of Using Same. WO2009020458.A1, ed USTPO. Alexandria, VA: E.I. Du Pont de Nemours and Company.

Allen, E., Xie, Z., Gustafson, A. M., and Carrington, J. C. (2005). microRNAdirected phasing during trans-acting siRNA biogenesis in plants. Cell 121, 207-221. doi: 10.1016/j.cell.2005.04.004

Arikit, S., Zhai, J., and Meyers, B. C. (2013). Biogenesis and function of rice small RNAs from non-coding RNA precursors. Curr. Opin. Plant Biol. 16, 170-179. doi: 10.1016/j.pbi.2013.01.006

Canales, C., Bhatt, A. M., Scott, R., and Dickinson, H. (2002). EXS, putative LRR receptor kinase, regulates male germline cell number and tapetal identity and promotes seed development in Arabidopsis. Curr. Biol. 20, 1718-1727. doi: 10.1016/S0960-9822(02)01151-X

Chaubal, R., Zanella, C., Trimnell, M. R., Fox, T. W., Albertsen, M. C., and Bedinger, P. (2000). Two male-sterile mutants of Zea mays (Poaceae) with an extra cell division in the anther wall. Am. J. Bot. 87, 1193-1201. doi: 10.2307/26 56657

Chaubal, R., Zanella, C., Trimnell, M. R., Fox, T. W., Albertsen, M. C., and Bedinger, P. (2003). The transformation of anthers in the mscal mutant of maize. Planta 216, 778-788. doi: 10.1007/s00425-002-0929-8

Chen, X. (2009). Small RNAs and their roles in plant development. Annu. Rev. Cell Dev. Biol. 25, 21-44. doi: 10.1146/annurev.cellbio.042308.113417

Creasey, K. M., Zhai, J., Borges, F., Van Ex, F., Regulski, M., Meyers, B. C., et al. (2014). miRNAs trigger widespread epigenetically activated siRNAs from transposons in Arabidopsis. Nature 508, 411-415. doi: 10.1038/nature13069

Cruz-Ramirez, A., Diaz-Triviño, S., Blilou, I., Grieneisen, V. A., Sozzani, R., Zamioudis, C., et al. (2012). A bistable circuit involving SCARECROWRETINOBLASTOMA integrates cues to inform asymmetric stem cell division. Cell 150, 1002-1015. doi: 10.1016/j.cell.2012.07.017

D'Arcy, W. G., and Keating, R. C. (1996). The Anther: Form, Function, Phylogeny. Cambridge: Cambridge University Press.

Esau, K. (1965). Plant Anatomy. 2nd Edn. New York, NY: John Wiley \& Sons, Inc.

Feng, X., and Dickinson, H. (2010). Tapetal cell fate, lineage and proliferation in the Arabidopsis anther. Development 137, 2409-2416. doi: 10.1242/dev. 049320

Hong, L., Tang, D., Zhu, K., Wang, K., Li, M., and Cheng, Z. (2012). Somatic and reproductive cell development in rice anthers is regulated by a putative glutaredoxin. Plant Cell 24, 577-588. doi: 10.1105/tpc.111.093740

Jackson, D. P., Allen, S. M., Johnston, R., Llaca, V., and Yang, F. (2013). Improving Agronomic Characteristics of Plants Through abph2. WO2013138399.A1, ed USPTO. Alexandria, VA: Cold Spring Harbor Laboratory; E.I. Du Pont de Nemours and Company.

Johnson, C., Kasprzewska, A., Tennessen, K., Fernandes, J., Nan, G., Walbot, V., et al. (2009). Clusters and superclusters of phased small RNAs in the developing inflorescence of rice. Genome Res. 19, 1429-1440. doi: 10.1101/gr.089854.108

Kapoor, M., Arora, R., Lama, T., Nijhawan, A., Khurana, J. P., Tyagi, A. K., et al. (2008). Genome-wide identification, organization and phylogenetic analysis of Dicer-like, Argonaute and RNA-dependent RNA Polymerase gene families and their expression analysis during reproductive development and stress in rice. BMC Genomics 9:451. doi: 10.1186/1471-2164-9-451

Kelliher, T., and Walbot, V. (2011). Emergence and patterning of the five cell types of the Zea mays anther locule. Dev. Biol. 350, 32-49. doi: 10.1016/j.ydbio.2010.11.005

Kelliher, T., and, Walbot, V. (2012). Hypoxia triggers meiotic fate acquisition in maize. Science 337, 345-348. doi: 10.1126/science. 1220080

Kelliher, T., and Walbot, V. (2014). Germinal cell initials accommodate hypoxia and precociously express meiotic genes. Plant J. 77, 639-652. doi: 10.1111/tpj.12414

Komiya, R., Ohyanagi, H., Niihama, M., Watanabe, T., Nakano, M., Kurata, N., et al. (2014). Rice germline-specific Argonaute MEL1 protein binds to phasiRNAs generated from more than 700 lincRNAs. Plant J. 78, 385-397. doi: 10.1111/tpj.12483
Li, J. S., and Torii, K. U. (2012). A tale of two systems: peptide ligand-receptor pairs in plant development. Cold Spring Harb. Symp. Quant. Biol. 77, 83-89. doi: 10.1101/sqb.2012.77.014886

Liu, B., Chen, Z., Song, X., Liu, C., Cui, X., Zhao, X., et al. (2007). Oryza sativa dicerlike4 reveals a key role for small interfering RNA silencing in plant development. Plant Cell 19, 2705-2718. doi: 10.1105/tpc.107.052209

Ma, H. (2005). Molecular genetic analyses of microsporogenesis and microgametogenesis in flowering plants. Annu. Rev. Plant Biol. 56, 393-434. doi: 10.1146/annurev.arplant.55.031903.141717

Moon, J., Skibbe, D., Timofejeva, L., Wang, C. J., Kelliher, T., Kremling, K., et al. (2013). Regulation of cell divisions and differentiation by MS32 is required for pre-meiotic anther development in Zea mays. Plant J. 76, 592-602. doi: $10.1111 /$ tpj. 12318

Murmu, J., Bush, M. J., DeLong, C., Li, S., Xu, M., Khan, M., et al. (2010). Arabidopsis basic leucine-zipper transcription factors TGA9 and TGA10 inter- act with floral glutaredoxins ROXY1 and ROXY2 and are redundantly required for anther development. Plant Physiol. 154, 1492-1504. doi: 10.1104/pp.110.159111

Nonomura, K.-I., Morohoshi, A., Nakano, M., Eiguchi, M., Miyao, A., Hirochika, H., et al. (2007). A germ cell specific gene of the ARGONAUTE family is essential for the progression of premeiotic mitosis and meiosis during sporogenesis in rice. Plant Cell 19, 2583-2594. doi: 10.1105/tpc.107.053199

Pekker, I., Alvarez, J. P., and Eshed, Y. (2005). Auxin response factors mediate Arabidopsis organ asymmetry via modulation of KANADI activity. Plant Cell 17, 2899-2910. doi: 10.1105/tpc.105.034876

Sanders, P. M., Bui, A. Q., Weterings, K., McIntire, K. N., Hsu, Y. C., Lee, P. Y., et al. (1999). Anther developmental defects in Arabidopsis thaliana male-sterile mutants. Sex. Plant Reprod. 11, 297-322. doi: 10.1007/s004970050158

Sheridan, W. F., Avalkina, N. A., Shamrov, I. I., Batygina, T. B., and Golubovskaya, I. N. (1996). The macl gene: controlling the commitment to the meiotic pathway in maize. Genetics 142, 1009-1020. doi: 10.1534/g3.112.004465

Singh, M., Goel, S., Meeley, R. B., Dantec, C., Parrinello, H., Michaud, C., et al. (2011). Production of viable gametes without meiosis in maize deficient for an ARGONAUTE protein. Plant Cell 23, 443-458. doi: 10.1105/tpc.110. 079020

Slotkin, R. K., Vaughn, M., Borges, F., Tanurdzić, M., Becker, J. D., Feijó, J. A., et al. (2009). Epigenetic reprogramming and small RNA silencing of transposable elements in pollen. Cell 136, 461-472. doi: 10.1016/j.cell.2008.12.038

Smyth, D. R., Bowman, J. L., and Meyerowitz, E. M. (1990). Early flower development in Arabidopsis. Plant Cell 2, 755-767. doi: 10.1105/tpc.2.8.755

Song, X., Wang, D., Ma, L., Chen, Z., Li, P., Cui, X., et al. (2012a). Rice RNAdependent RNA polymerase 6 acts in small RNA biogenesis and spikelet development. Plant J. 71, 378-389. doi: 10.1111/j.1365-313X.2012.05001.x

Song, X., Li, P., Zhai, J., Zhou, M., Ma, L., Liu, B., et al. (2012b). Roles of DCL4 and DCL3b in rice phased sRNA biogenesis. Plant J. 69, 462-474. doi: 10.1111/j.1365-313X.2011.04805.x

Timofejeva, L., Skibbe, D. S., Lee, S., Golubovskaya, I., Wang, R., Harper, L., et al. (2013). Cytological characterization and allelism testing of pre-meiotic anther developmental mutants identified in a screen of maize male sterile lines. G3 3, 231-249. doi: 10.1534/g3.112.004465

Toriba, T., Suzaki, T., Yamaguchi, T., Ohmori, Y., Tsukaya, H., and Hirano, H. Y. (2010). Distinct regulation of adaxial-abaxial polarity in anther patterning in rice. Plant Cell 22, 1452-1462. doi: 10.1105/tpc.110.075291

Vernoud, V., Laigle, G., Rozier, F., Meeley, R. B., Perez, P., and Rogowsky, P. M. (2009). The HD-ZIP IV transcription factor OCL4 is necessary for trichome patterning and anther development in maize. Plant J. 59, 883-894. doi: 10.1111/j.1365-313X.2009.03916.x

Wang, C.-J. R., Nan, G.-L., Kelliher, T., Timofejeva, L., Vernoud, V., Golubovskaya, I. N., et al. (2012). Maize multiple archesporial cell 1 (mac1), an ortholog of rice TDL1A, modulates cell proliferation and identity in early anther development. Development 139, 2594-2603. doi: 10.1242/dev.077891

Xing, S., and Zachgo, S. (2008). ROXY1 and ROXY2, two Arabidopsis glutaredoxin genes, are required for anther development. Plant J. 53, 790-801. doi: 10.1111/j.1365-313X.2007.03375.x

Yang, W.-C., Ye, D., Xu, J., and Sundaresan, V. (1999). The SPOROCYTELESS gene of Arabidopsis is required for initiation of sporogenesis and encodes a novel nuclear protein. Genes Dev. 13, 2108-2117. doi: 10.1101/gad.13.16.2108

Zhai, J., Jeong, D. H., De Paoli, E., Park, S., Rosen, B. D., Li, Y., et al. (2011). MicroRNAs as master regulators of the plant NB-LRR defense gene family via 
the production of phased, trans-acting siRNAs. Genes Dev. 25, 2540-2553. doi: 10.1101/gad.177527.111

Zhai, L., Sun, W., Zhang, K., Jia, H., Liu, L., Liu, Z., et al. (2014). Identification and characterization of Argonaute gene family and meiosis-enriched Argonaute during sporogenesis in maize. J. Integr. Plant Biol. doi: 10.1111/jipb.12205. [Epub ahead of print].

Zhang, D., and Li, Y. (2014). Specification of tapetum and microsporocyte cells within the anther. Curr. Opin. Plant Biol. 17, 49-55. doi: 10.1016/j.pbi.2013.11.001

Zhang, D., Xue, L., and Zhu, L. (2011). Cytological analysis and genetic control of rice anther development. J. Genet. Genomics 38, 379-390. doi: 10.1016/j.jgg.2011.08.001

Zhang, H., Egger, R., Kelliher, T., Morrow, D. J., Fernandes, J., Nan, G.-L., et al. (2014). Transcriptomes and proteomes define gene expression progression in pre-meiotic maize anthers. G3 4, 993-1010. doi: 10.1534/g3.113.009738

Zhao, D. Z., Wang, G. F., Speal, B., and Ma, H. (2002). The EXCESS MICROSPOROCYTES1 gene encodes a putative leucine-rich repeat receptor protein kinase that controls somatic and reproductive cell fates in the Arabidopsis anther. Genes Dev. 16, 2021-2031. doi: 10.1101/gad.997902

Zhu, J., Chen, H., Li, H., Gao, J. F., Jiang, H., Wang, C., et al. (2008). Defective in Tapetal development and function 1 is essential for anther development and tapetal function for microspore maturation in Arabidopsis. Plant J. 55, 266-277. doi: 10.1111/j.1365-313X.2008.03500.x

Conflict of Interest Statement: Timothy Kelliher and Virginia Walbot are inventors on a patent application (61/598.544) filed by Stanford University entitled "Method for Modulating the Number of Archesporial Cells in a Developing Anther." The authors declare that the research was conducted in the absence of any commercial or financial relationships that could be construed as a potential conflict of interest.

Received: 31 May 2014; accepted: 28 June 2014; published online: 21 July 2014.

Citation: Kelliher T, Egger RL, Zhang H and Walbot V (2014) Unresolved issues in pre-meiotic anther development. Front. Plant Sci. 5:347. doi: 10.3389/fpls.2014.00347 This article was submitted to Plant Evolution and Development, a section of the journal Frontiers in Plant Science.

Copyright (c) 2014 Kelliher, Egger, Zhang and Walbot. This is an open-access article distributed under the terms of the Creative Commons Attribution License (CC BY). The use, distribution or reproduction in other forums is permitted, provided the original author(s) or licensor are credited and that the original publication in this journal is cited, in accordance with accepted academic practice. No use, distribution or reproduction is permitted which does not comply with these terms. 